\title{
Addressing Fairness Issues in the Carbon Tax Law: The Case of British Columbia, Canada
}

\author{
Tsung-Sheng Liao* \\ Department of Law, National Chung Cheng University, 168, University Rd., \\ Min-Hsiung Township, Chiayi County, Taiwan 62102 \\ Received 22 May 2018 \\ Revised 19 June 2018; Accepted 21 June 2018
}

\begin{abstract}
The effects on the environment as a consequence of climate change are severe, especially those caused by anthropogenic greenhouse gas emission. It is necessary to internalize these external costs caused by human activities. Taxes should be levied on polluters so as to reduce pollution. Thus, accompanied with appropriate complementary measures and policies, carbon taxes are effective to mitigate emission of $\mathrm{CO}_{2}$. As the carbon tax system in British Columbia, Canada has achieved notable effectiveness, it is worth further studying and analyzing, and can become a model for Taiwan.
\end{abstract}

Keywords: Climate change, Carbon Tax, Revenue-Neutral Tax, Carbon Tax Act, Greenhouse Gas Reduction and Management Act.

\section{Introduction}

Recently, the effects on the environment as a consequence of climate change are severe, especially the problem causing from anthropogenic greenhouse gas emissions. Among greenhouse gases, emissions of carbon dioxide $\left(\mathrm{CO}_{2}\right)$ account for the majority. Therefore, governments start to implement relative policies and strategies to deal with the problem, that is, too much $\mathrm{CO}_{2}$ in the atmosphere.

Carbon taxes play a significant role to reduce the emissions of $\mathrm{CO}_{2}$.Accompanying

\footnotetext{
*Tel.: 84-86-5-272041135115

Email: lawts1@ccu.edu.tw

https://doi.org/10.25073/2588-1167/vnuls.4154
}

with appropriate complementary measures and policies, carbon taxes are effective to mitigate emissions of $\mathrm{CO}_{2}$. The carbon tax in British Columbia, Canada achievesnotable effectivenessand is worth further studying and analyzing.

This article is composed of five parts including a short Introduction and Conclusion. Part two will discuss the origin, mechanisms and merits of carbon taxes. Part three will explain the carbon tax in British Columbia, including legal framework, the important principle and complementary measures of the Carbon Tax Act. Part four will show the effectiveness and economic effect of the carbon tax in British Columbia. 


\section{Carbon Taxes}

\subsection{The Development of Carbon Tax Systems}

The concept of carbon taxes can be dated back to 1920 when Arthur Pigou, a British economist came up with the idea of Pigouvian taxes in his book "The Economics of Welfare". $\mathrm{He}$ argues that it is necessary to internalize the external costs associated with environmental pollutions caused by human activities ${ }^{2}$. Taxes should be levied on polluters so as to reduce pollutions ${ }^{3}$. In the context of environmental economics, environmental pollutions have negative externalities, not calculated into production costs for private sectors ${ }^{4}$. This undermines the utility of environmental resources and reduces the availability of social welfare. It is not fair for the public to assume the costs of negative externalities ${ }^{5}$. To resolve this problem, Pigou suggested tax levy as a means to internalize external costs and hence to enhance the utility of environmental resources ${ }^{6}$.

According tothe report, State and Trends of Carbon Pricing, published by the World Bank, many countries scheduled for implementation or have implementednational or regional carbon tax systems [1]. In Northern Europe, Finland, Norway, Sweden, Demark, Estonia and Iceland have implemented or planned for carbon taxes ${ }^{7}$.In 1990, Finland became the first country in the world that imposed a carbon tax [2]. The initial rate was US\$1.41/ $/ \mathrm{tCO}_{2}$ [3]. The fuels exempt from the tax were peat, natural gas and imported fuels used by the timber or manufacturing industry ${ }^{8}$. After years of development, the carbon tax and energy tax

\footnotetext{
${ }^{1}$ SeeArthur Cecil Pigou, The Economics of WELFARE (4th ed. 1932).

${ }^{2} I d$.

${ }^{3} I d$.

${ }^{4} I d$.

${ }^{5} \mathrm{Id}$.

${ }^{6} \mathrm{Id}$.

${ }^{7} I d$.

${ }^{8} \mathrm{Id}$.
}

were integrated in $2013^{9}$. Cogeneration plants enjoy a $50 \%$ carbon tax reduction for the fuels they use ${ }^{10}$. Sweden began to levy a carbon tax in 1991, by combining the previous energy tax and lowering the energy tax rate by half [4]. Currently, the general carbon tax level is approximately US $\$ 150 / \mathrm{tCO}_{2}{ }^{11}$. Energies used to generate electricity and from renewable energy are exempt ${ }^{12}$. Industries enjoy a $50 \%$ tax reduction but non - industrial consumers pay the carbon tax based on their electricity consumption ${ }^{13}$.

Other European countries that are levying carbon taxes or have schedules for implementation are Poland, Latvia, Slovenia, Switzerland, Ireland, the UK, France and Portugal [5]. The UK began to impose acarbon tax in 2013 [6]. The system sets a "carbon price floor' and the minimum price paid for carbon emissions from fossil fuels producers [7]. If the carbon price in the European Union is lower than in the UK, producers have to pay the difference to the British Treasury ${ }^{14}$. Ireland imposeda carbon tax in 2010, at an initial rate was $€ 15 / \mathrm{tCO}_{2}$. It went up to $€ 20 / \mathrm{tCO}_{2}$ in 2012 [8]. The carbon tax covers almost all families, industries, farms and other users of fossil fuels [9]. In 2013, solid fuels (such as coal) were included ${ }^{15}$.

In Americas, countries that have scheduled for implementation or have implemented carbon taxes are Canada (British Columbia and Alberta), Mexico and Chile [10]. Chile published a new carbon tax bill in 2014 and will enact in 2018 [11]. The tax rate will be $\$ 5$ $/ \mathrm{tCO}_{2}$ and it only covers $55 \%$ of emissions in Chile [12]. In Oceania, New Zealand was planning to impose acarbon tax but eventually

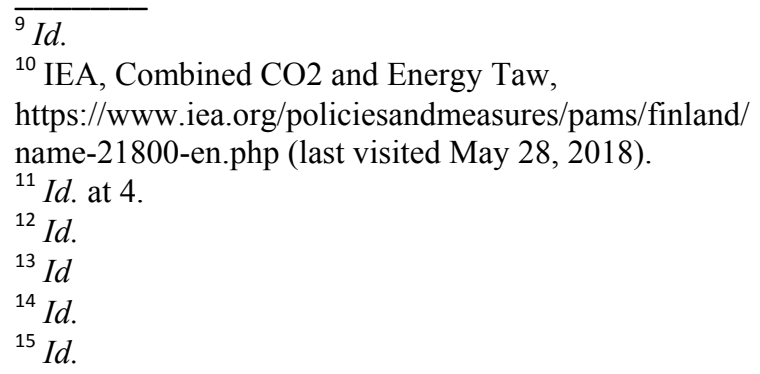


aborted the idea ${ }^{16}$. Australia charged acarbon tax in 2012 but repealed the taxation in $2014^{17}$.

\subsection{The Mechanism of Carbon Tax Systems}

Carbon taxes are levied on carbon dioxide emissions, mostly based on energy generation or consumption.Its mathematical formula is the tax base multiplied by tax rate. The purpose is to reduce greenhouse gas emissions by measures, such as tax rate adjustment, to encourage businesses and retail users to cut back on energy consumption, or to adopt technologies.

A carbon tax consists of four elements: tax bases, taxpayers, tax rates and tax revenues. Tax bases of a carbon tax refer to the taxable items, taxation requirements and exemptions [13]. Tax bases come from two categories, fossil fuels and biofuels. They can also be divided into combustion and non-combustion types, depending on the ways with which carbon dioxide is generated [14]. Fossil fuels include coal, gasoline, diesel and natural gases. The combustion of fossil fuels generates $\mathrm{CO}_{2}$ emissions ${ }^{18}$. Biofuels such as wood, ethanol and biodiesels, also generate $\mathrm{CO}_{2}$ when burned. However, the formation of biofuels consumes $\mathrm{CO}_{2}$ through photosynthesis. Therefore, biofuels are carbon neutral. In addition, $\mathrm{CO}_{2}$ can also be generated via non-combustion activities such as composting in agricultural sectors, the disposal of solid waste, and waste water treatment, although these activities emit less $\mathrm{CO}_{2}$. The decision over tax bases and exemptions should take into account energy mix of a country and $\mathrm{CO}_{2}$ emissions across industries.

Taxpayers, obligated to contribute to tax revenues, may be emission producers or consumers or both. There is political feasibility to levy on emission producers, because those taxes arenot directly paid by the public(who are not taxed). However, emission producers may transfer the increased costs to consumers indirectly. In contrast, the levy on consumers is a more effective means of carbon emission

\footnotetext{
${ }^{16}$ Carbon Tax Center, supra note 20

${ }^{17} \mathrm{Id}$.

${ }^{18}$ Id. at $522-29$.
}

reductions as energy services are provided for the public. This also creates a level even playing field for both domestic and imported carbons, by avoiding the unfair competition for importers or exporters who pay carbon taxes [15].

Tax rate issues include starting rates, the increase or decrease of tax rates over a period of time, the frequency of tax rate adjustments and other considerations for tax rate adjustments. Initial rates are determined on the basis of $\mathrm{CO}_{2}$ equivalent of tax bases, energy mix, effectiveness of carbon emission reductions and other government policies. In general, tax rates are low to start with in order to enhance political feasibility and public acceptance [16].

The utilization of Tax revenues refers to the spending of tax revenues [17]. Tax revenues may be used to incentivize the corporates or individuals who have been effectively reducing $\mathrm{CO}_{2}$ emissions or investing in $\mathrm{R} \& \mathrm{D}$ of renewable energy by lowering their business or personal income tax rates or offsetting their business or income taxes payable. Tax revenues can also be used to eliminate the unfairness of the carbon tax policies. For instance, there is a gap between the rich and the poor in terms of carbon tax burdens measured against income levels. Therefore, it is possible to provide subsidies or income tax reductions with tax revenues [18]. Another example is the subsidy to the residents in remote areas who may see an increase in transportation expenses as a result of carbon taxes ${ }^{19}$.

\subsection{The Merits of Carbon Taxes}

In many regards, carbon taxes serve as a power tool for carbon emission reductions. The merits of carbon taxes are (1) high predictability and transparency of tax revenues; (2) feasibility and manageability; (3) long-term revenue sources and flexibility in utilization for the government.

Carbon taxes are highly predicable and transparent. It is possible to adjust tax rates according to the effectiveness of carbon

${ }^{19}$ Id. at 160 . 
emission reductions. By calculating carbon price, emission sources can be planned and investments in new carbon reduction technologies can be made over a long term [19]. Also, carbon taxes provide management flexibility to emission sources [20]. When tax rates are higher than carbon reduction costs, emission sources will seek to cut back emissions $^{20}$. On the contrary, if tax rates are lower than carbon reduction costs, emission sources will opt for an increase in emissions ${ }^{21}$ Furthermore, the carbon tax system is transparent with information easily accessible to the public. That avoids political or economic manipulations for personal interests [21].

The simple structure of carbon taxes can effectively reduce administrative costs andbe implemented quickly ${ }^{22}$. Since it is possible to precisely define the carbon contents for different tax rates, carbon taxes are relatively uncomplicated [22]. Carbon taxes can piggyback the existing tax framework, laws and regulations ${ }^{23}$. Compared to other carbon reduction mechanisms, the implementation costs for carbon taxes are lower ${ }^{24}$. Meanwhile, the relative simplicity of carbon taxes makes it possible to be rolled out quickly to reduce $\mathrm{CO}_{2}$ emissions ${ }^{25}$.

Carbon taxes provide stable and long-term revenues for the governments. Tax revenues can be used to fund policies to reduce $\mathrm{CO}_{2}$ emissions and mitigate the impact of climate change. Revenues can be used to subsidize the development of clean technologies and renewable energy [23]. Tax credit or business income tax cut may be provided to incentivize carbon reductions ${ }^{26}$. Subsidies may be distributed to low-earners and disadvantaged groups so that their economic status will not be significantly and adversely affected by carbon

\footnotetext{
${ }^{20} I d$.

${ }^{21} \mathrm{Id}$.

${ }^{22}$ Kerr, supra note 38.

${ }^{23} \mathrm{YeH}$, supra note 42, at 93.

${ }^{24} \mathrm{Id}$. at 95 .

${ }^{25}$ Kerr, supra note 38.

${ }^{26} \mathrm{Id}$.
}

$\operatorname{taxes}^{27}$. Also, financial support may be extended to the industries heavily impacted to help them to transform their businesses.

\section{The Carbon Tax in British Columbia}

\subsection{The legal framework of the Carbon Tax}

Under the framework of Canadian climate change policies, British Columbia began to formulate its own regulations concerning climate changein 2007. The Greenhouse Gas Reduction Target Actentered into effect in January 2008 in British Columbia. That Act aims for (1) at least 33\% reductions from the 2007 levels by 2020; (2) at least $80 \%$ reductions from the 2007 levels by 2050 [24].

Following the Greenhouse Gas Reduction Target Act, British Columbia enacted the Carbon Tax Act in 2008, and became the first region in North America that imposed a carbon tax [25]. The design of the carbon tax system takes into consideration the tax bases, tax rates, taxpayers and use oftax revenues ${ }^{28}$. It also takes into account local particularities and assesses the possible consequences. Complementary measures are put in place. As a result, the success of British Columbia in its carbon taxation has significantly reduced $\mathrm{CO}_{2}$ emissions, without compromising the local economy or causing major burdens on the public.

The Carbon Tax Act has 157 articles, which can be divided into 14 parts:(1) Interpretation (Article 1); (2) Plans and Reports Respecting the Carbon Tax (Article 2) (repealed by 2017.12.10): Requiring finance minister to meet the revenue neutral by preparing plans and reports; (3) Imposition of Tax and Setting the Rate of Tax (Article 8): Specifying the timing of the tax imposition and tax rate calculation. All taxable fossil fuels and tax rates are presented tabular in format as an annex to the carbon tax act; (4) Exemptions and Credits

\footnotetext{
${ }^{27} \mathrm{Id}$.

${ }^{28}$ Duff, supra note 30.
} 
(Article 14): Considering specific circumstances such as double taxation and overseas carbon dioxide emissions; (5) Collection of Tax and Security (Article 15): Since carbon tax is direct tax, taxes are directly collected by the fuel seller who was approved for tax collection; (6) Refunds (Article 36): Money will be refunded when a carbon tax should not be levied; (7) Tax Collection Administration (Article 43): Regulating the right of authorities of checking, auditing tax, as well as estimating the tax; (8) Appeals (Article 56): People may appeal to the Minister and the court about any non-compliance; (9) Recovery of Amounts Owing (Article 59): Regulating the treatmenton people who do not pay taxes; (10) Part 10 (Article 69) to Part 14 are General Provisions, Offences and Penalties, Regulations, Transitional Provisions, and Consequential Amendments [26].

It is obvious that the Carbon Tax Act has detailed and concrete content. As a result, it is not difficult to implement provisions ofthe Actfor the government of British Columbia. And it is easy for the public to understand and comply with the carbon tax.That increasesits acceptability for people.

\subsection{The fair and revenue-neutral Carbon Tax}

The revenue-neutral design is the key to success for the carbon tax in British Columbia. That makes the carbon tax more attractive than the carbon trading in terms of public finance, social welfare and public acceptance ${ }^{29}$. The purpose of revenue-neutraltax plan is to avoid overly heavy burdens on taxpayers as a result of a carbon tax. In addition, the British Columbia government can allocate carbon tax revenues as planned or redistribute the wealth to ensure social justice.

The budgets and fiscal plans released by the Ministry of Finance, British Columbia (2008 2010), provide a glimpse of its revenueneutralmechanism. The table below, Revenue

\footnotetext{
${ }^{29}$ Shaw, Hung\& Lo,supra note 39, at 6.
}

NeutralCarbon Tax Plan, illustrated the amount of most tax revenue and of whichthe corresponding distribution to individuals and businesses during 2008-2010 [27]. The tax credits or reductions for individuals were divided into the low-income category and the general category. Also, as the communities in the north are far away from metropolitan areas, residents are unable to enjoy a robust network of public transport. The levy of carbon taxes on transport fuels would also put the rural citizens in a disadvantage. Therefore, part of the tax revenues was used to subsidize the residents in the northern and rural areas at $\$ 200$ per annum $^{30}$.

The second part of the Carbon Tax Act dealt with the planning and reporting and articulated the revenue neutral obligations of the Ministry of Finance ${ }^{31}$. The annual plan and report in compliance with the Act shall be prepared and submitted to the Legislative Assembly $^{32}$. The planning horizon should cover three fiscal years and the following issues for each year: (1) a forecast of the carbon tax revenues to be collected; (2) the revenue measures that the minister proposes to be implemented; (3) a forecast of the reductions in the provincial revenues as a result of the revenue measures ${ }^{33}$. Any intended adjustment by the Minister of Finance shall be reported to the Legislative Assembly as required ${ }^{34}$.

The last section of the second part of the Actstipulates that any failure by the Minister of Finance to submit to the Legislative Assembly regarding fiscal estimates or adjustments with the statutory period will lead to a $15 \%$ salary cut pursuant to the regulations set forth in the Members' Remuneration and Pensions Act of British Columbia ${ }^{35}$.

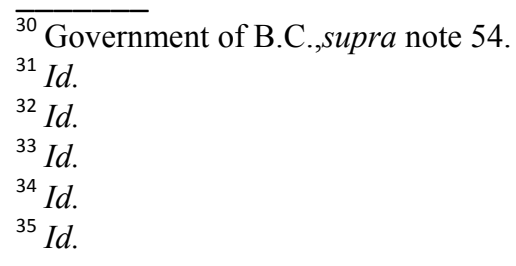




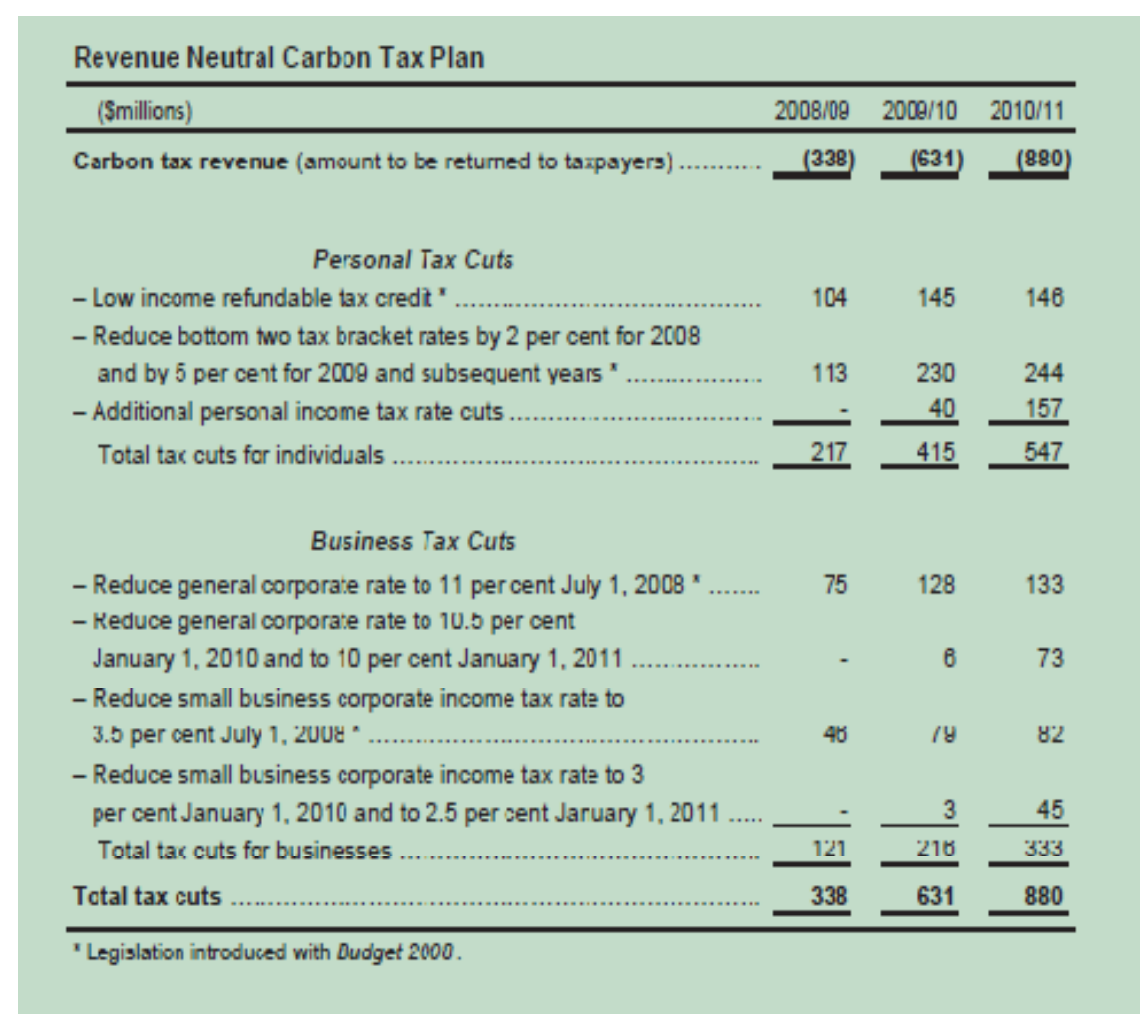

\subsection{Complementary measuresof the Carbon Tax}

The robust legal framework is important for the carbon tax in British Columbia. The carbon tax system specifies the levy on fuels purchased for transport and other purposes and states the tax rates per annum to enable easiness and transparency in management and administration $^{36}$. In the purpose of economic effectiveness, fixed tax rates ensure stability compared to the carbon trading, which is subject to market fluctuations ${ }^{37}$. The adherence of revenue-neutral tax plans maintains the economic efficiency of British Columbia ${ }^{38}$. Whilst carbon taxes are not able to provide a forward-looking insight on pricing and volumes measured by environmental effects as in the case of the carbon trading, the taxation on all the fuel users has a sweeping impact on

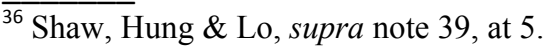

${ }^{37}$ Id. at 6 .

${ }^{38}$ Id.
}

consumers' behavior and energy consumption in the long term. This will make a low carbon society happen and the success of British Columbia is a case in point.

In addition to regulatory designs, the British Columbia government ensures the effectiveness of the carbon tax with legal transparency and complementary measures. The transparency of the regulatory regime is materialized with a report once every two years since 2008 when the action plans in with greenhouse gas reductions kicked off [28]. These reports disclose whether the action plans have been gradually moving toward the targets ${ }^{39}$. As described in the principle of revenue neutrality, the Minister of Finance is required to develop taxation and fiscal plans for revenue neutrality. The biennial reports are published on the British Columbia's government website. All the researchers and the general public are able to

${ }^{39} I d$. 
access relevant information easily and collectively review the execution and effectiveness of the carbon tax. The transparency has significantly enhanced the acceptance of public of the carbon tax levy.

\section{Control of greenhouse gas emissions and economic effects of the Carbon Tax in British Columbia}

British Columbia is the first region in North America that imposed carbon taxes. Its carbon taxation is also known for the comprehensiveness of carbon pricing, as it covers $70 \%$ of greenhouse gas emissions in British Columbia. This was why it has been effective in controlling and reducing greenhouse gas emissions.According to the national statistics of Canada in 2017, British Columbia emitted approximately 61 million tons of carbon in 2015, up 17\% from 1990 but down $8 \%$ from 2008. In terms of emissions per capita, it went from 17.6 tons in 1990 to 15.4 tons in 2008, and further dropped to 13.9 tons in 2014, after the launch of carbon taxes [29]. As far as the emission density is concerned, it stood at 4.9 million tons for each one million of Canadian dollars in 1990, 3.3 million in 2008 and 2.9 million in $2014^{40}$. All these numbers indicate the improvement in economic development and energy efficiency in British Columbia $^{41}$. In sum, British Columbia witnesses a steady decline in the total volumes, emission per capita and emission density of greenhouse gas emissions. This demonstrates the effectiveness of the carbon tax in the reduction of greenhouse gas emissions.

Statistics suggest that the implementation of the carbon tax have not created any adverse influence on the economic development ofBritish Columbia. From 2007 to 2014, the GDP of British Columbia grew 12.4\% [30]. The levy of the carbon tax prompt companies to seek out for innovative and clean energy technologies. The effective reductions of greenhouse gas emissions are the means to mitigate the increase in production costs as a result of the carbon tax. This is also why more jobs are being created in British Columbia. From 2010 to 2014, the number of new clean energy jobs wasapproximate 68,000 and up $12.5 \%$ [31]. The gross production value of the clean energy industry totaled 6.3 billion Canadian dollars in 2014, and was up $19.3 \%$ or so from 2010.

The promotion of clean tech and renewable energy supports the economy sustainability and creates green jobs ${ }^{42}$. The carbon tax in British Columbia is a message to the market that greenhouse gas reductions are a catalyst for the development local industries ${ }^{43}$. The carbon tax policies drive the investment and growth of technologies deployed to reduce greenhouse gas emissions, by prompting large polluters to seek innovative and energy efficient ways of productions or business models in order to save energy costs and lower tax burdens. The carbon tax policies in British Columbia has effectively lowered the greenhouse gas emissions and created market advantages to low-carbon industries. This has brought British Columbia into a new era of low-carbon economy.

\section{Conclusion}

The main issue on the reduction of $\mathrm{CO}_{2}$ emissions is to be addressed by governments. Many countries have adopted carbon taxes as the instrument to reduce $\mathrm{CO}_{2}$ emissions and worked well. However, there are some suspicions that whether it will adversely affect the economy resulted from the use of carbon taxes. Consequently, it is worth while for us to take reference from the successful example of the design and implementation of the carbon taxation in British Columbia, which is effective

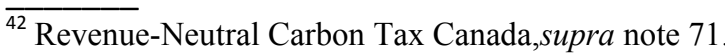
${ }^{43} \mathrm{Id}$.
}

\section{${ }^{40} I d$. \\ ${ }^{41} I d$.}


to reduce $\mathrm{CO}_{2}$ emissions without having negative implication on the economic development.

The article has argued that carbon taxes which supplemented with appropriate measures are effective to reduce $\mathrm{CO}_{2}$, and the carbon taxation in British Columbia isworthy reference for the governments. In particular, the principle of revenue neutrality in British Columbia addresses many problems, and one of them is the challenge of fairness. Government of British Columbia returns all tax revenues to individuals and corporates, especially in vulnerable groups (such as low-income group), which sorts out the problem of fairness ${ }^{44}$.

\section{References}

[1] World Bank, State and Trends of Carbon Pricing (2017), at http://documents.worldbank.org/curated/en/4688 81509601753549/pdf/120810-WP-PUBLIC-wbreport-171027.pdf (last visited May 28, 20148).

[2] World Bank, State and Trends of Carbon Pricing (2014), at79, http://documents.worldbank.org/curated/en/505431 468148506727/pdf/882840AR0REPLA00EPI 2102 680Box38522.pdf (last visited May 28, 2018).

[3] LSE, The 2015 Global Climate Legislation Study,http://www.lse.ac.uk/Granthaminstitute/w p-content/uploads/2015/05FINLAND.pdf (last visited May 28, 2018).

[4] Bengt Johansson, Economic Instrument in Practice 1: Carbon Tax in Sweden,at 3,

\footnotetext{
${ }_{44}$ In Taiwan, the Greenhouse Gas Reduction and Management Act is used to combat the implication of global climate change and the problem of the greenhouse gas. It provides the legal basis for enacting a carbon tax, although there is no carbon taxation in Taiwan so far. The greenhouse gas reduction act establishes a long-term emissions target for 2050 of $50 \%$ less than 2005. Also the Act sets on a five-year basis goal since 2016 of the greenhouse gas emissions in Taiwan. Although there are many challenges to enact the carbon tax act for the government of Taiwan, it is worth pursuing one like that in British Columbia.
}

https://www.oecd.org/sti/inno/2108273.pdf (last visited Jan. 15, 2018).

[5] World Bank, supra note 7.

[6] World Bank, supra note 9, at 83.

[7] Carbon Tax Center, Where Carbon Is Taxed, https://www.carbontax.org/where-carbon-istaxed. (last visited Jan. 25, 2018).

[8] OECD,Ireland's Carbon Tax and the Fiscal Crisis, 59 ENVIRONMENT WORKING PAPERS 1, 3 (2013).

[9] Elisabeth Rosenthal, Carbon Taxes Make Ireland Even Greener, The New York Time, at A1 (Dec. 28, 2012).

[10] World Bank, supra note 7.

[11] Kate Galbraith, Climate Change Concerns Push Chile to Forefront of Carbon Tax Movement, N.Y. Time, (Oct. 29, 2014), https://www.nytimes.com/2014/10/30/business/in ternational/climate-change-concerns-push-chileto-forefront-of-carbon-tax-movement.html.

[12] Ministry of Finance, Chile, Tax Reform to Amend the System of Income Taxation and Introduce Various Adjustments in the Tax System, http://www.leychile.cl/Nevegar?idNorma=10671 94 (last visited Jan. 10, 2018).

[13] David G. Duff, Carbon Taxation in British Columbia, 10 VT. J. ENVT. L. 87, 91 (2008).

[14] Gilbert E. Metcalf \& David Weisbach, The Design of a Carbon Tax, 33 HARV. ENVTL. L. REV. 499, 529 (2009).

[15] Janet E. Milne, Carbon Taxes in the United States: The Context for the Future, 10 VT. J. ENVT. L. 1, 19(2008).

[16] James M. Poterba, Global Warming Policy: A Public Finance Perspective, 7 JOURNAL OF ECONOMIC PERSPECTIVES 47, 54(1993).

[17] Milne, supra note 33, at 19-20.

[18] Karen Bubna-Litic \& Nathalie J. Chalifour, Are Climate Change Policies Fair to Vulnerable Communities? The Impact of British Columbia's Carbon Tax and Australia's Carbon Pricing Policy on Indigenous Communities, 35 DALhousie L. J., 127, 133 (2012).

[19] Alex Rice Kerr, Why We Need a Carbon Tax, 34 ENVTL.L. \& POL'Y J. 69, 92 (2010).

[20] Daigee Shaw, Chih-Ming Hung\& Shih-Fang Lo, A Comparison of Carbon Tax and Carbon Trading and an Examination of Their Compatibility, 747 MONTHLY JOURNAL OF TAIPOWER'S ENGINEERING 59, 63 (2010).

[21] Jiunn-rong Yeh, Climate Change Governance and Law 96 (2015). 
[22] Michael J. Zimmer, In This Issue: Climate Law Reporter: Carbon Tax: Ready for Prime Time, 8 Sustainable Development L. \& Pol'y.67, 70 (2008).

[23] nJesse Reiblich, Addressing Climate Change: Have the Political Winds Shifted in Favor of a Carbon Tax?,2 LSU J. OF ENERGY L. \& RESOURCES 49, 67 (2013).

[24] Government of B.C.,Canada, Greenhouse Gas Reduction Targets Act, Nov. 29, 2007, Art. 2: "(1) The following targets are established for the purpose of reducing $\mathrm{BC}$ greenhouse gas emissions:(a) by 2020 and for each subsequent calendar year, $\mathrm{BC}$ greenhouse gas emissions will be at least $33 \%$ less than the level of those emissions in 2007; (b) by 2050 and for each subsequent calendar year, BC greenhouse gas emissions will be at least $80 \%$ less than the level of those emissions in 2007.",http://www.bclaws.ca/EPLibraries/bclaws _new/document/ID/freeside/00_07042_01 (last visited Jan. 14, 2018).

[25] Wan-Jiun Chen, On Carbon Taxes in Taiwan Based on the Successful Carbon Taxes Model in
British Columbia, Canada, 66 BANK OF TAIWAN QUARTERLY 130, 130 (2015).

[26] Government of B.C., Canada, Carbon Tax Act, http://www.bclaws.ca/EPLibraries/bclaws_new/d ocument/ID/freeside/00_08040_01\#part9(last visited Jan. 10, 2018).

[27] Ministry of Finance of B.C., Canada, Budget and Fiscal Plan 2008/09 - 2010/11, at 15 (2008), http://www.bcbudget.gov.bc.ca/2008/bfp/2008_Bud get_Fiscal_Plan.pdf (last visited May 28, 2018).

[28] Government of B.C., Canada, Climate Action Plan,http://www2.gov.bc.ca/gov/content/environ ment/climate-change/planning-and-action (last visited Jan. 10, 2014).

[29] British Columbia Government,Trends in Greenhouse Gas Emissions in B.C. (1990-2014), http://www.env.gov.bc.ca/soe/indicators/sustainabi lity/ghg-emissions.html (last visitedJan. 10, 2018).

[30] Revenue-NeutralCarbon Tax Canada, http://unfccc.int/secretariat/momentum_for_chan ge/items/9931.php (last visited Jan. 10, 2018).

[31] DelphiGroup, West Coast Clean Economy: 20102014 Jobs Update 6 (2015), http://delphi.ca/wpcontent/uploads/2015/12/PCC-Clean-EconomyReport-FINAL.pdf(last visited Jan. 10, 2018).

\title{
Giải quyết vấn đề công bằng trong Luật Thuế carbon: Trường hợp của British Columbia, Canada
}

\author{
Tsung-Sheng Liao \\ Khoa Luật, Đại học Quốc gia Chung Cheng, \\ Số 168, đuoòng Đại học, thị trấn Minxiong, huyện Chiayi, Đài Loan, 62102
}

Tóm tắt: Những ảnh hưởng đến môi trường do hậu quả của biến đổi khí hậu rất nghiêm trọng, đặc biệt là vấn đề phát sinh từ khí thải nhà kính do con người gây ra. Nó là cần thiết để nội bộ hóa các chi phí bên ngoài gây ra bởi các hoạt động của con người. Thuế phải được đánh vào người gây ô nhiễm để giảm ô nhiễm. Vì vậy, đi kèm với các biện pháp và chính sách bổ sung phù hợp, thuế carbon có hiệu quả để giảm thiểu phát thải $\mathrm{CO}_{2}$. Trong khi đó, hệ thống thuế carbon ở British Columbia, Canada đạt được hiệu quả đáng chú ý, đáng được nghiên cứu và phân tích sâu hơn, và có thể trở thành một mô hình cho Đài Loan.

Tù khóa: Biến đổi khí hậu, thuế carbon, thuế thu nhập trung bình, luật thuế carbon, đạo luật quản lý và giảm thiểu khí nhà kính. 